\title{
FORUM GUMEULIS : UPAYA PENINGKATAN KOMPETENSI GURU DALAM MENULIS KARYA ILMIAH DI KOTA TASIKMALAYA
}

\author{
Caswita \\ SDN Saguling Kecamatan Kawalu Kota Tasikmalaya \\ caswitamaulana@gmail.com \\ https://doi.org/10.36052/andragogi.v8i1.122 \\ Diterima: 11 April 2020 | Disetujui: 09 Juni 2020 | Dipublikasikan: 30 Juni 2020
}

\begin{abstract}
Abstrak
Tujuan penelitian ini untuk mendiskripsikan upaya peningkatan kompetensi guru dalam membuat KTI melalui kegitan forum Gumeulis di Kota Tasikmalaya, melalui pelatihan, bimbingan, pendampingan dan praktik langsung. Metode penelitian yang digunakan adalah penelitian kulaitatif dengan jenis studi kasus. Teknik pengumpulan data melalaui wawancara, observasi dan studi dokumentasi. Hasil penelitian menunjukkan: (1) peningkatan kompetensi guru di kota Tasikmalaya dalam membuat KTI lebih efektif dilakukan melalui kegiatan forum guru menulis. (2) pengembangan kompetensi profesional guru dalam membuat KTI melalui kegiatan forum Gumeulis menunjukan adanya peningkatan kompetensi guru. (3) melalui forum Gumeulis terjadi saling interkasi bersama-sama belajar membuat KTI. (4), Forum Gumeulis dapat terbentuk iklim akademik yang kondusif dalam meningkatkan kompetensi guru membuat KTI. Kesimpulan penelitian menunjukan bahwa dengan cara belajar secara bersamasama dalam komunitas akan dapat meningkatkan kompetensi guru dalm menulis KTI. Hal tersebut karena diantara sesama anggota dapat saling berdiskusi dan belajar bersama. Dibawah bimbingan guru senior dalam komunitas terebut.
\end{abstract}

Kata kunci: forum Gumeulis, kompetensi profesional, guru, KTI

\begin{abstract}
[FORUM GUMEULIS: EFFORTS TO IMPROVE TEACHER COMPETENCE IN WRITING SCIENTIFIC PAPERS IN TASIKMALAYA CITY] The purpose of this study is to describe efforts to improve teacher competency in making $K T I$ through the activities of the Gumeulis forum in the City of Tasikmalaya, through training, guidance, mentoring and hands-on practice. The research method used is a qualitative research with a type of case study. Data collection techniques through interviews, observation and study of documentation. The results showed: (1) improvement of teacher competency in the city of Tasikmalaya in making KTI more effectively carried out through teacher writing forums. (2) the development of teacher professional competence in making KTI through the Gumeulis forum activities shows an increase in teacher competency. (3) through the Gumeulis forum there is mutual interaction together to learn to make Eastern Indonesia. (4), the Gumeulis Forum can create a conducive academic climate in improving teacher competency in creating KTI. The conclusion of the research shows that by learning together in the community will be able to improve the competence of teachers in writing KTI. This is because among members can discuss and learn together. Under the guidance of senior teachers in the community.
\end{abstract}

Keywords: Gumeulis forum, professional competence, teacher, KTI 


\section{PENDAHULUAN}

$P$

roblem yang masih menjadi perhatian pemerintah terkait profesionalisme guru adalah lemahnya guru dalam membuat karya tulis ilmiah. Problem tersebut tidak hanya terjadi di wilayah tertentu, hampir semua daerah mengalami problem yang sama. Tidak sedikit guru yang gagal naik pangkat atau masih ditangguhkan kenaikan pangkatnya, dikarenakan tidak terpenuhinya penulisan KTI sebagai salah satu persyaratan kenaikan pangkat. Fakta menunjukkan bahwa sebanyak 8.729 orang guru mengalami kegagalan dalam kenaikan pangkat dikarenakan adanya temuan bahwa hasil KTI-nya terindikasi sebagai hasil jiplakan (Okenews, 2015). Kegagalan kenaikan pangkat 188 guru, juga terjadi di Karangasem Bali (NusaBali.com, 2016). Senada hal tersebut, ditemukan dugaan sindikat transaksi kenaikan pangkat yang dilakukan oleh dua orang Guru Gowa Sulawesi Selatan (Amir, 2019). Berdasarkan data-data tersebut, dapat digambarkan bahwa keterampilan guru dalam menulis KTI diberbagai daerah masih cukup lemah.

Upaya pemerintah telah banyak dilakukan dengan berbagai program baik melalui pelatihan, lomba menulis, PKB atapun programprogram lainnya. Gerakan literasi sekolah merupakan salah contoh program saat ini yang digalakan untuk meningkatkan literasi di sekolah. Namun demikian menurut pendapat peneliti program dari pemerintah saja tidak cukup, perlu adanya kesadaran dari guru itu sendiri untuk meningkatkan profesionalismenya, terutama dalam membuat karya tulis ilmiah.

Hal tersebut terlihat dari hasil penelitian dibeberapa daerah diantaranya penelitian dari Catur Hari Wibowo Tesis IAIN Surakarta tahun 2015 (Wibowo, 2015). Hasil penelitian menunjukan problematika profesi guru yang terjadi di Madrasah Tsanawiyah Negeri di Kabupaten Wonogiri meliputi dua faktor yakni: faktor internal dan faktor eksternal. Faktor internal berasal dari dalam diri pribadi guru, yaitu lemahnya sentuhan pedagogik, didaktik, metodik, serta kurang mencintai profesinya merupakan indikasi ketidakselarasan kompetensi guru pada umumnya. Sedangkan faktor eksternal berasal dari luar lingkungan guru, seperti ukuran kelas yang besar, karena kekurangan lokal dan berpengaruh pada situasi atau suasana belajar di kelas, fasilitas dan sumber belajar yang kurang memadai, terutama laboratorium yang belum dimiliki madrasah dan terpenting terutama yang menyangkut lingkungan kerja, misalnya: upah kerja yang dapat memenuhi kebutuhan, suasana/iklim kerja yang menggairahkan, sikap jujur dan pengertian di kalangan pekerja, dapat dipercaya dari kalangan pemimpin terwujud dalam kenyataan, adanya penghargaan terhadap hasrat dan kebutuhan yang berprestasi serta sarana yang menunjang bagi kesejahteraan mental dan fisik, seperti tempat olah raga, masjid dan rekreasi.

Penelitian lainnya juga menunjukan hal yang tidak jauh berbeda, seperti penelitian yang dilakukan oleh Noorjannah (2014). Dari hasil penelitian tersebut menjelaskan bahwa sebagian besar kegiatan guru di sekolah-sekolah lebih berorientasi pada misi pendidikan dan pengajaran di kelas sedangkan visi dan misi ilmiah dalam bentuk penulisan dan publikasi ilmiah sering terabaikan. Implikasi dari kenyataan tersebut, penulisan dan publikasi karya ilmiah di kalangan guru masih memprihatinkan. Hal ini ditandai dengan rendahnya produktivitas guru dalam menulis dan mempublikasikan karya ilmiah.

Kepala Pusat Perbukuan Depdiknas sebagaimana dikutip oleh Nugroho (2011) menyatakan bahwa guru yang bisa menulis tidak lebih dari $1 \%$. Banyak faktor penghambat yang menyebabkan para guru memiliki produktivitas yang rendah dalam menulis karya ilmiah. Tidak bisa dipungkiri bahwa budaya menulis masyarakat Indonesia khususnya guru masih rendah, sehingga menjadi salah satu penyebab kesulitan guru dalam membiasakan diri menulis karya ilmiah.

Kelemahan guru dalam membuat karya tulis ilmiah, tidak boleh dibiarkan terus menerus begitu saja. Harus ada solusi bagaiman hal tersebut segera teratasi. Sehingga dibutuhkan ikhtiar dari berbagai pihak yang berkepentingan. Utamanya ada keinginan atau motivasi dari diri guru. Kompetensi guru tidak akan meningkat dengan sendirinya akan tetapi harus ada upaya untuk meningkatkannya. Kompetensi guru dapat ditingkatkan melalui berbagai cara antara lain mengikuti pendidikan dan latihan, sertifikasi guru, penelitian tindakan kelas, melalaui 
organisasi profesi, komunitas belajar. Peningkatan kompetensi guru menjadi hal yang sangat penting pada institusi sekolah karena memiliki pengaruh yang sangat signifikan terhadap efektivitas sebuah sekolah. Tanpa adanya guru yang memiliki kompetensi akan sulit dicapai tujuan pembelajaran yang telah ditetapkan.

Guru menjadi kunci utama akan keberhasilan dalam proses pendidikan. Sebaik apapun fasilitas pendidikan tidak akan banyak manfaat tanpa adanya peran guru yang baik. Sebaliknya fasilitas pendidikan yang minim akan dapat dimaksimalkan oleh guru yang profesional.

Hal tersebut dikarenakan guru dalam amanat Undang-undang Republik Indonesia No.14 tahun 2005 tentang guru dan dosen merupakan tenaga profesional yang mempunyai fungsi, peran, dan kedudukan yang sangat penting dalam mencapai visi pendidikan yaitu menciptakan insan Indonesia cerdas dan kompetitif. Selanjutnya berkewajiban untuk untuk selalu mengembangkan keprofesiannya secara berkelanjutan.

Guru merupakan salah satu komponen sistem pendidikan yang menentukan keberhasilan pendidikan. Seburuk apapun kualitas sumber daya sekolah, proses belajar mengajar masih tetap bisa berjalan sepanjang ada guru yang mengajar dan siswa yang belajar. Proses belajar mengajar yang berjalan akan berkualitas jika guru mampu kreatif mendayagunakan sumber daya sekolah dan lingkungannya guna menunjang keefektifan proses belajar siswa-siswanya. Seperti yang dikatakan oleh Harsanto (2007:10), keberhasilan implementasi pembelajaran sangat ditentukan oleh pemahaman para pemangku kepentingan, utamanya ialah guru. Guru sebagai pendidik di sekolah adalah profesi yang istimewa. Tidak cukup jika profesi pendidik sekadar dikategorikan semata-mata sebagai suatu jenis "pekerjaan" dimana mereka bekerja untuk dibayar dan kemudian selesai begitu saja. Profesi seorang pendidik, lebih dari hanya sekedar menjalankan pekerjaannya sebagai guru yang hanya menyampaikan materi di kelas. Profesi pendidik memiliki misi, pengabdian, bahkan merupakan sebuah ibadah yang memiliki nilai (value) lebih dibandingkan dengan jabatan dan profesi lainnya. Pendidik (guru) adalah sebuah jabatan profesional yang memiliki visi, misi, dan aksi yang khusus sebagai pemeran utama dalam pengembangan manusia sebagai sumber daya.

Lebih lanjut Afandi (2015:87) juga mengatakan hal yang serupa bahwa guru merupakan kunci keberhasilan pendidikan dengan tugas profesional dan didukung oleh kompetensinya. Guru berfungsi membantu orang lain (peserta didik) untuk belajar dan berkembang; membantu perkembangan intelektual, personal dan social warga masyarakat yang memasuki sekolah. Untuk menjalankan profesinya secara profesional, guru dituntut untuk memiliki kompetensi dan pengalaman dalam kegiatan pembelajaran. Kompetensi guru terdiri atas empat kompetensi yang terdiri atas: kompetensi pedagogik, sosial, kepribadian, dan profesional.

Hasil penelitian dari Ayusrijuniantari (2017:10), menyatakan bahwa diantara pengaruh kompetensi guru terhadap hasil belajar siswa adalah pengetahuan, keterampilan, dan sikap guru atau kompetensi guru sangat menentukan proses pembelajaran di kelas dan pendidikan di sekolah. Kompetensi guru akan menentukan mutu lulusan suatu pendidikan, karena peserta didik belajar langsung dari para guru. Jika kompetensi guru rendah, maka proses pembelajaran tidak akan berjalan efektif dan menyenangkan. Jika pembelajaran tidak efektif dan menyenangkan, maka peserta didik sulit menerima dan menyerap serta memahami pelajaran. Guru dengan tingkat kognitif yang tinggi akan cenderung berfikir abstrak, imajinatif, kreatif, dan demokratis. Guru seperti ini akan lebih fleksibel dalam melaksanakan tugas, bahkan memiliki hubungan yang baik dengan siswa dan teman sejawatnya. Bekal awal yang harus dimilki seorang guru sebelum mengajar adalah menguasai keempat kompetensi guru. Kompetensi guru ini akan meningkatkan kinerja guru dan profesionalisme guru, dengan kompetensi yang dimiliki, seorang guru akan mampu menguasai materi dan mampu menyampaikan materi dengan baik dan mudah dimengerti oleh peserta didik.

Selain kesadaran diri dari seorang guru dalam peningkatan profesionalnya. Dibutuhkan peran kepala sekolah sebagai pimpinan lembaga 
pendidikan untuk membantu dalam peningkatan profesionalisme guru. Kepala sekolah sebagai pengendali harus membawa sekolah yang dipimpin menjadi sekolah yang berkualitas. Seperti yang dikatakan Sudrajat (2008) bahwasanya kepala sekolah sebagai pengelola memiliki tugas mengembangkan kinerja personel, terutama meningkatkan kompetensi profesional guru." Yang dimaksud dengan kompetensi profesional di sini, tidak hanya berkaitan dengan penguasaan materi semata, tetapi mencakup seluruh jenis dan isi kandungan kompetensi. Oleh karena itu, kepemimpinan kepala sekolah harus dapat memberdayakan semua komunitas sekolah untuk dapat meningkatkan kompetensinya dalam mencapai tujuan pendidikan yang telah ditetapkan.

Kepala sekolah tanggung jawab besar terhadap peningkatan kompetensi guru. Peran tersebut diantaranya pertama, kepala sekolah memfasilitasi guru untuk melakukan pengembangan diri melalui program pelatihan tentang bagaimana melakukan penelitian tindakan kelas atau KTI lainnya. Kedua melakukan pendampingan dalam membuat KTI atau pelaksanaan PTK. Ketiga, menyediakan fasilitas sarana dan prasarana (termasuk perlengkapan mengajar) secara efektif dan efisien. Dengan demikian, guru dapat memanfaatkan sarana dan prasarana serta perlengkapan yang tersedia di sekolah dengan sebaik-baiknya.

Lebih lanjut menurut Wahyosumidjo (2010:90) bahwa peran kepala sekolah sebagai pemimpin mencerminkan tanggung jawab kepala sekolah untuk menggerakkan sumber daya yang ada di sekolah. Fungsi kepemimpinan amat penting sebab disamping sebagai penggerak juga berperan sebagai kontrol segala aktifitas guru (dalam rangka peningkatan profesional mengajar), staff, siswa dan sekaligus untuk meneliti persoalan-persoalan yang timbul di lingkungan sekolah.
Menurut Sagala (2007), diantara peran kepala sekolah adalah menyediakan fasilitas pembelajaran, melakukan pembinaan pertumbuhan jabatan guru, dan dukungan profesionalitas lainnya menjadi suatu kekuatan tersendiri bagi guru melaksanakan tugas profesionalnya

Selanjutnya menurut Mudlofir (2012:32) profesionalisme dan sikap profesional merupakan motivasi intrinsik yang ada pada diri guru sebagai pendorong untuk mengembangkan dirinya menjadi tenaga profesional yang pada akhirnya akan berdampak terhadap munculnya etos kerja yang unggul.

Sedangkan menurut Inayati (2014:12) profesionalisme guru adalah kondisi, arah, tujuan dan kualitas suatu keahlian dan kewenangan dalam bidang pendidikan dan pengajaran yang berkaitan dengan pekerjaan seseorang yang menjadi mata pencaharian.

Seorang guru yang profesional harus memiliki beberapa keahlian diantaranya adalah pertama menguasai karakteristik peserta didik yang dilayani secara mendalam dengan berbagai variasi karakter dan cara pendekatannya, kedua menguasai bidang ilmu atau sumber (bahan ajar) dari segi disclipinary content maupun pedagogical content; ketiga, menguasai pendekatan pembelajaran yang mendidik; dan keempat, mengembangkan profesionalitas secara berkelanjutan (Rakajoni, 2008).

Menurut Aqib (2007:10), Dalam rangka pengembangan profesi guru, ada lima kegiatan yang bisa dilakukan diantaranya yaitu pertama menghasilkan karya tulis ilmiah di bidang pendidikan. Kedua, menemukan teknologi tepat guna bidang pendidikan, ketiga, menciptakan alat peraga. Keempat, menghasilkan karya seni, dan kelima, mengikuti kegiatan pengembangan penyempurnaan kurikulum. Dari kelima kegiatan tersebut yang paling banyak disoroti adalah kelemahan guru dalam menyusun karya tulis ilmiah atau KTI.

Sampai saat ini kemampuan guru secara umum masih lemah terutama dikalangan guru jenjang sekolah dasar. Salah satu yang menjadi fakor penyebabnya adalah guru merasa aman berada posisi saat ini, guru tidak mau keluar dari zona nyaman. Kemamapuan guru dalam menulis karya ilmiah belum disadari sebagai kewajiban profesionalnya. KTI masih dianggap sebagai 
syarat untuk kebutuhan teknis kenaikan pangkat semata, bukan untuk memperbaiki kinerja.

Upaya pemerintah dalam mendorong guru melakukan PTK ternyata belum optimal. Hal ini dapat dilihat dari belum banyak guru yang melakukan PTK. Berdasarkan data dari Badan Kepegawaian Nasional tahun 2015 tercatat bahwa 1.461 .124 guru, 22,87\% adalah guru golongan IVA, $0,16 \%$ golongan IVB, $0,006 \%$ guru goongan IVC, $0,0001 \%$ golongan IVD, dan $0,00 \%$ guru golongan IVE, sedangkan sisanya golongan IVA ke bawah. Berdasarkan data di atas, dapat dilihat bahwa golongan kepangkatan guru mengalami stagnasi pada golongan IVA. Stagnasi tersebut disebabkan karena untuk naik ke jenjang kepangkatan berikutnya guru diharuskan menulis KTI salah satunya dapat berupa PTK (Putriani, 2016:3).

Hal tersebut terbentur karena keterbatasan kemampuan guru dalam membuat karya ilmiah sebagai syarat wajib kenaikan pangkat pada jenjang tersebut. Kelemahan guru dalam membuat karya tulis harus segera diatasi, kompetensi guru dalam menulis harus ditingkatkan dengan berbagai cara. Berdasarkan hasil penelitian dari Sampurno \& Siswanto (2010) menyimpulkan bahwa 390.000 guru berpangkat IV/a masih mengalami kesulitan untuk kenaikan pangkat berikutnya karena adanya persyaratan menullis karya tulis ilmiah. Jika mengacu pada temuan tersebut, maka dapat diketahui para guru kurang pengetahuan dan kemampuan tentang pembuatan karya tulis ilmiah. Program pendampingan penulisan artikel ilmiah bagi guru menjadi hal yang krusial dan mendesak untuk dilakukan.

Sejak diberlalukannya Permenpan-RB Nomor 16 Tahun 2009 syarat peningkatan profesi guru melalui angka kredit yaitu wajib bagi guru untuk melampirkan karya ilmiah. Namun demikian fakta di lapangan menunjukkan bahwa guru dihadapkan persoalan ketika harus melaksanakan pengembangan diri, dan melakukan penelitian di kelas. Hal ini disebabkan adanya keterbatasan waktu dan pembiayaan baik dari pemerintah maupun sekolah tempat guru bertugas (Lestari, 2019).

Menulis karya ilmiah seharusnya menjadi budaya akademik yang melekat pada profesi guru, namun demikian kenyataan di lapangan guru SD masih sedikit yang mau dan mampu untuk menulis. Padahal hal itu menjadi salah satu cara meningkatkan kompetensi profesional guru, karena sudah diatur Undang-undang No. 14 tahun 2005 tentang Guru dan Dosen. Diperlukan upaya bagaiaman memberikan motivasi, bimbingan, sarana media untuk dapat meningkatkan kompetensi guru dalam menulis karya ilmiah.

Siagian (2002) menyatakan bahwa pengembangan mutu sumber daya manusia penting dilakukan untuk memberikan pengetahuan dan keterampilan yang memadai untuk melaksanakan tugas; memberikan berbagai pengetahuan dan keterampilan yang dibutuhkan pegawai untuk dapat fleksibel dan adaptif dengan strategi dan teknologi baru memberikan pengetahuan dan keterampilan yang dibutuhkan personel jika diberi tugas yang belum pernah dilakukannya; meng-upgrade pengetahuan dan keterampilan personel yang telah usang akibat dari perkembangan ilmu pengetahuan dan teknologi. Selain hal tersebut, Dermawati (2017) menyebutkan bahwa faktor yang mempengaruhi tercapainya tujuan pembelajaran dan pendidikan di sekolah tidak berdiri sendiri, tetapi dipengaruhi latar belakang pendidikan, pengalaman mengajar, dan lamanya mengajar.

Penulis sebagai kepala sekolah berupaya untuk meningkatkan kompetensi guru dalam menulis karya ilmiah. Karya ilmiah yang menjadi fokus adalah karya ilmiah populer di media massa. Dipilihnya penulisan artikel ilmiah populer dimedia massa karena artikel di media ide massa sangat berbeda dengan tulisan jurnal ilmiah, skripsi, tesis atau disertasi yang mempunyai aturan yang sangat baku, sementara artikel ilmiah populer lebih fleksibel. Artike ilmiah populer ditulis berdasarkan isu kekinian, aktual dan menjadi perhatian publik. Tulisan dengan gaya bahasa ilmiah populer diharapkan dapat menjadi solusi atas problematika pendidikan yang sedang berlangsung.

\section{METODE PENELITIAN}

Penelitian ini menggunakan metode kualitatif. Menurut Sukmadinata (2011:60), penelitian kualitatif merupakan penelitian untuk mendeskripsikan dan menganalisis fenomena, peristiwa, aktivitas sosial, sikap kepercayaan, persepsi, pemikiran secara individual maupun 
kelompok. Sementara itu menurut Arikunto (2002:11), penelitian kualitatif adalah penelitian naturalistic. Istilah "naturalistic" menunjukkan bahwa pelaksanaan penelitian ini memang terjadi secara alamiah, apa adanya, dalam situasi normal yang tidak dimanipulasi keadaan dan kondisinya, menekankan pada deskripsi secara alami. Pengambilan data atau penjaringan fenomena dilakukan dari keadaan yang sewajarnya ini dikenal dengan sebutan "pengambilan data secara alami atau natural.

Sedangkan teknik pengumpulan data dilakukan dengan menggunakan wawancara mendalam (in-depth interview), pengamatan partisipatif (participant observation) dan dokumentasi (documentation). Untuk mendapatkan informasi lebih mendalam tentang suatu kasus. Wawancara didesain untuk mengetahui persepsi, motivasi, sikap, tingkah laku dari orang-orang yang diwawancarai. Alasan menggunakan wawancara mendalam adalah untuk memusatkan perhatian pada kasus yang intensif dan mendetail melalui pengumpulan data, penyusunan data, analisis data dan interprestasi data.

Untuk memperoleh data yang lebih lengkap dan mendalam, wawancara dan pengamatan dilakukan lebih dari satu kali. Selain itu juga dilakukan wawancara dengan informan lain (cek dan ricek data) untuk memperkaya, melengkapi dan memunculkan kebenaran data. Sumber data yang dikumpulkan dalam penelitian ini adalah data dari responden dan data dokumentasi. Subjek penelitian atau responden penelitian ini adalah guru anggota forum guru menulis, yang berasal dari SDN Saguling Kecamatan Kawalu Kota Tasikmalaya yang berjumlah 10 orang guru.

\section{TEMUAN DAN PEMBAHASAN}

\section{Temuan}

Dalam rangka meningkatkan mutu peserta didik, Pemerintah telah mengeluarkan Permendikbud Nomor 23 tahun 2015 tentang penumbuhan budi pekerti (PBP). Di mana salah satu implementasinya adalah kegiatan pembiasaan baik di lingkungan sekolah. Diantara kegiatan pembiasaan tersebut salah satunya adalah pembiasaan membaca buku non pelajaran 15 menit sebelum pembelajaran dimulai. Namun demikian, kegiatan tersebut tidak akan berjalan dengan maksimal tanpa dimulai dari guru itu sendiri.

Oleh karena itu berbagai program peningkatan kualitas pendidikan harus dimulai dari guru. Guru harus terus belajar untuk meningkatkan kompetensinya baik secara berkelompok ataupun secara mandiri. Guru harus senantiasa belajar kapanpun di manapun dan dengan cara apapun. Keberadaan sebuah komunitas belajar menjadi alternatif belajar di luar pendidikan formal.

Melalui komunitas belajar yang ada diharapkan para guru dapat membangun iklim akademik yang mendukung peningkatan kompetensinya. Baik dalam komunitas belajar formal atau kelompok kerja guru yang formal. Komunitas belajar merupakan sarana untuk menciptakan habits literasi di kalangan guru. Kegiatan tersebut dilaksanakan pada waktu luang setelah mengajar.

Salah satu komunitas belajar yang telah dibangun untuk menggerakan dunia literasi di kalangan para guru adalah forum guru menulis, selanjutnya disingkat forum Gumeulis. Forum Gumeulis dideklarasikan pada hari kamis tanggal 26 Pebruari 2015 di Tasikmalaya. Forum Gumeulis merupakan gerakan kutural yang dibangun atas kesadaran bersama di antara para guru di Tasikmalaya dan sekitarnya untuk meningkatkan kompetensi bidang menulis karya ilmiah.

Selama ini yang menjadi problem para guru dalam menulis belum dapat diatasi secara tuntas. Kehadiran forum Gumeulis diharapkan mampu mengatasi persoalan ini. Keberadaan forum gumelis wadah untuk belajar secara bersama-sama, berdiskusi, bertukar pikiran untuk saling berbagi dan belajar dalam menulis. Forum Gumeulis diharapkan menjadi wadah alternatif untuk para guru belajar tentang menulis dan sekaligus wadah kajian isu-isu pendidikan kontemporer.

Komitmen awal pendiriannya forum Gumeulis merupakan wadah untuk membangun tradisi menulis di kalangan guru. Karena merupakan gerakan kultural diharapkan forum Gumeulis keberadaanya dapat bertahan lama. Gerakan yang diinisiasi dari bawah atas dasar keinginan sendiri, biasanya akan lebih langgeng. Dibandingkan dengan kegiatan yang bersifat instruksi apalagi paksaan. 
Sebagai forum diskusi dan sarana belajar, forum gumuelis juga menghadirkan para narasumber dari akademisi dan praktisi. Akademisi berasal dari dosen yang sudah terbiasa menulis karya ilmiah. Sementara dari praktisi berasal dari kalangan media yaitu pimpinan redaksi salah satu media massa.

Forum Gumeulis mengusung gerakan revolusioner dalam menggerakan sekaligus mempercepat guru untuk berani dan bisa menulis. Forum ini mengusung pembelajaran yang tidak terlalu banyak teori akan tetapi langsung pada praktek menulis. Apapun bentuk dan hasilnya dari tulisan tidak terlalu dipermasalahkan yang terpenting adalah guru berani mulai menulis apa yang menjadi ide gagasannya. Walaupun demikian yang selalu ditanamkan di kalangan anggota forum Gumeulis adalah larangan melakukan plagiasi. Apabila mau mengutip pendapat orang lakukan secara ilmiah yaitu dengan cara mencantumkan sumbernya. Plagiat sangat dilarang karena merupakan kejahatan intelektual, yang dapat menjatuhkan martabat penulis sendiri.

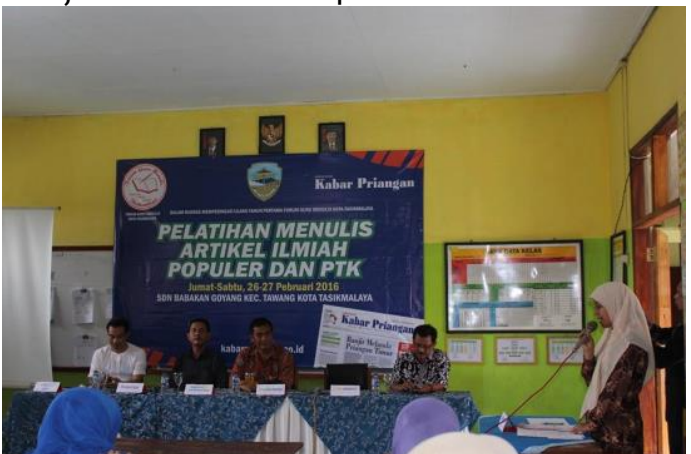

Gambar 1 : Kegiatan Pekatihan Oleh Forum Gumeulis sebagai komnitas belajar

\section{Pembahasan}

SDN Saguling merupakan sekolah negeri yang terletak di jalan saguling kec. Kawalu kota Tasikmalaya, dengan akreditasi A. Jumlah guru keseluruhan 10 orang. Pangkat dan golongan ruang, di SDN Saguling rata-rata golongan III dan IV, namun belum semua guru melaksanakan peningkatan profesi melalui penulisan karya ilmiah. Selain itu, upaya guru di SDN Saguling dalam meningkatkan profesinya melalui kegiatan menulis karya ilmiah belum terlihat secara maksimal.

Kepala sekolah memiliki tanggung jawab yang besar dalam proses pembelajaran. Kepala sekolah pemimpin bertanggungjawab untuk meningkatkan kompetensi guru melalui Manajemen sumber daya manusia. Dengan kata lain, unsur yang berperan dalam peningkatkan profesionalisme guru di antaranya adalah kepala sekolah (Susanto \& Muhyadi, 2016:152).

Dibutuhkan peran kepala sekolah untuk meningkatakan kompetensi guru dalam menulis karya ilmiah. Diantara tugas dan fungsi kepala sekolah adalah motivator, hal tersebut sering disebut dengan singkatan EMASLIM yaitu berperan sebagai educator, manager, administrator, supervisor, leader, inovator dan motivator. Lebih lanjut peran kepala sekolah sebagai manajer sekolah diharapkan terus aktif dalam membimbing serta mendorong guru melakukan kagiatan yang menunjang profesi keguruan. Kepala sekolah juga memiliki peran sebagai: pertama, pendidik; kedua, administrator; ketiga, supervisor; dan keempat wirausahawan (Daryanto, 2011).

Sementara itu Dalam prespektif kebijakan pendidikan nasional (Depdiknas, 2006) terdapat tujuh peran utama kepala sekolah, yaitu sebagai: (1) edukator (pendidik), (2) manajer; (3) administrator; (4) supervisor (penyedia); (5) leader (pemimpin; (6) pencipta iklim kerja, dan (7) wirausahawan. Selain itu, kepala sekolah juga harus mampu mendayagunakan semua sumber daya yang ada di sekolah. Oleh karena itu kepala sekolah mempunyai tugas yang sangat penting dalam mengembangkan kualitas pendidikan.

Pada akhirnya pelatihan model apapun harus didasari oleh kemauan guru untuk meningkatkan kometensinya. Sebagaimana dikatakan oleh Wardhana (Wardhana 2016:268), bahwasannya program apapun yang direncanakan untuk peningkatan kompetensi guru tidak akan berjalan maksimal jika tidak didukung oleh kemauan guru dalam mengembangkan kompetesni dirinya. Oleh karena itu pemerintah dan pemangku kepentingan termasuk pemerhati pendidikan membutuhkan upaya serius dalam hal peningkatan kompentensi guru. Program internal sekolah harus dialokasikan yang terkait dengan peningkatan kompetensi guru. Direncanakan dengan matang dan dilaksanakan dengan penuh tanggung jawab. Program tersebut dapat berupa pelatihan, peningkatan Teknologi Informasi, perencanaan kurikulum, 
menambah kelengkapan sarana prasarana dan sebagainya. Karena jika masalah dasar kapabilitas internal guru ini tidak tersentuh maka seluruh program yang dijalankan tidak akan memberikan hasil yang berarti.

Pelaksanaan kegiatan peningkatan kompetensi guru yang dilakukan penulis sebagai kepala sekolah di SDN Saguling, dengan melibatkan pihak lain yaitu media massa dan forum guru menulis. Hal tersebut agar guru-guru SDN Saguling mempunyai pengalaman baru.

Tahap Pelaksanaan kegiatan peningkatan kompetensi menulis KTI adalah :

\section{a. Perencanaan}

Pada tahap perencanaan ini kepala sekolah melakukan penjajakan dengan melakukan sosialisasi berdialog dengan para guru, terutama guru yang masih golongan III. Dari hasil diskusi tersebut para guru pada dasarnya ingin membuat KTI walapun masih hanya sebatas untuk kenaikan pangkat. Jumlah guru di SDN Saguling berjumlah 10 orang, semua guru pada dasarnya sudah mengenal apa yang dimaksud dengan KTI. Pengetahuan tentang KTI dalam pemahaman guru masih hanya sebatas penelitian tindakan kelas atau PTK. Pada prakteknya guru masih jarang melaksanakan PTK kecuali apabila ada keperluan kenaikan pangkat.

Pada tahap perencanaan penulis sebagai kepala sekolah meperkenalkan ragam KTI selain PTK, diantaranya yaitu artikel imiah populer di media massa.

\section{b. Pelaksanaan}

Pada tahap pelaksanaan 10 orang guru SDN Saguling diperkenalkan dengan media massa yang sudah ada di sekolah yaitu kabar priangan. Dalam media massa ini memiliki kolom khusus untuk artikel guru tentang pendidikan yaitu kolom guru menulis. Kolom ini sengaja dibuka oleh pihak redaksi sebagai kerja sama dengan forum Gumeulis (guru menulis). Komunitas forum Gumeulis merupakan komunitas literasi yag dibentuk oleh penulis sendiri pada tahun 2015. Merupakan bentuk kegelisahan penulis akan minimnya kamampuan guru menulis. Forum Gumeulis dibangun untuk saling berbagai, berdiskusi dan berlatih untuk sesama rekan guru dalam hal menulis.
Melalui forum Gumeulis guru SDN Saguling didorong untuk aktif berkegiatan terkait penguatan literasi. Diantara kegiatan yang dilakukan adalah diskusi rutin sebulan sekali dikantor redaksi kabar priangan dengan dipandu oleh para redaktur. Pelatihan menulia PTK, penerbitan web berita, diskusi buku, penerbitan jurnal, dan kegiatan lainnya yang terkait dengan kepenulisan.

Guru SDN Saguling diharapkan saling mendukung dengan cara belajar dari mereka yang telah berhasil. Melalui forum Gumeulis sedikitnya 10 orangg guru telah mampu berkoprah diajang nasional dan tulisannya terbit di berbagai media, misalnya menjadi juara pada seminar nasional kesharlindung, juara literasi, simposium dan lain sebagainya. Selain itu dengan aktif di forum Gumeulis tulisan guru dapat terbit di media massa kabar priangan, salah satu media cetak group pikiran rakyat.

Diantara kegiatan yang diakukan oleh guruguru dalam komunitas forum Gumeulis adalah;

1) Studi Lapangan ke Media Massa

Forum Gumeulis menyadari bahwasannya media massa merupakan sarana yang paling strategis untuk menggerakan budaya literasi. Oleha karena itu kerja sama dengan pihak media massa mutlak dilakukan untuk mendukung gerakan literasi yang di gelorakan oleh forum Gumeulis. Dalam hal ini forum Gumeulis menggandeng salah satu media massa terbesar dan terpercaya di wilayah priangan timur yaitu kabar priangan. Media massa lokal yang merupakan bagian dari pikiran rakyat group media terbesar di Jawa Barat. Kerjasama yang dibangun berlandaskan saling memberikan manfaat bukan saling memanfaatkan. Forum Gumeulis meyakini bahwasannya media massa merupakan sarana komunikasi untuk menyebarkan gagasan yang paling efektif. Sebaliknya Media massa juga perlu membangun hubungan yang harmonis dengan pembacaanya.

Berdasarkan landasan kerja sama tersebut forum Gumeulis dengan media massa membuat program-program yang dapat menggerakan literasi di kalangan guru. Di antara program tersebut yaitu, pertama mengadakan pelatihan menulis karya ilmiah populer. Sebagai upaya mengembangkan karir guru. Sehingga solusi kebuntuan kenaikan pangkat guru dapat teratasi. Dari pihak media massa menjadi 
narasumber utama dari pelatihan tersebut. Pelatihan dilakukan secara berkala di titik-titik tertentu yang menjadi pusat kegiatan. Materi pelatihan meliputi materi tentang menulis artikel ilmiah populer di media massa, kiat jitu menembus media massa, dan praktek membuat artikel.

Program kedua adalah mengadakan diskusi secara rutin terkait dengan isu-isu kontemporer pendidikan, dengan terlebih dahulu setiap anggota wajib membaca satu buku atau artikel jurnal terkait dengan tema kekinian yang sebelumnya telah ditentukan. Program kerja sama yang ketiga adalah kunjungan ke media yang di agendakan sebulan sekali. Kegiatan ini merupakan literasi media dengan tujuan mengetahui proses penerbitan berita dari mulai reportase di lapangan sampai terbit menjadi sebuah berita di koran.

Selanjutnya yang keempat adalah kerja sama yaitu menerbitkan tulisan para anggota Gumeulis melalui rubrik khusus yang telah disediakan oleh media massa. Kolom tersebut disiapkan untuk menerbitkan artikel guru yang kemudian diberi nama rubrik guru menulis. Rubrik ini menjadi kebanggaan sendiri bagi forum Gumeulis, karena merasa diberi kepercayaan untuk mengisi pada rubruk kolom tersebut. Guru yang baru memulai menulis akan merasa bangga dan percaya diri manakala tulisannya bisa terbit di media massa dan dibaca banyak orang. Selanjutnya akan menjadi pemicu semangat guru untuk terus menulis. Selain itu manfaat praktisnya tulisan yang telah dimuat dapat menjadi syarat angka kredit untuk kenaikan pangkat.

Berdasarkan hasil wawancara dengan guru anggota forum Gumeulis, melalui jalinan kerja sama tersebut sangat banyak sekali manfaatnya. Manfaat tersebut diantaranya selain dapat menggerakan dan memberdayakan guru dalam dunia literasi juga dapat menciptakaan iklim akademik melalu berdiskusi dan saling mengkaji karya ilmiah. Itulah kegiatan yang terus di bangun forum Gumeulis dengan pihak media massa. Langkah kedepan tidak menutup kemungkinan dapat bekerja sama dengan pihakpihak lain yang dapat mendukung gerakan literasi di kalangan pendidik, misalnya dengan perpustakaan nasional atau daerah, perguruan tinggi, komunitas literasi dan lain sebagainya.
Dengan tujuan yang sama yaitu mencerdasakan anak bangsa.

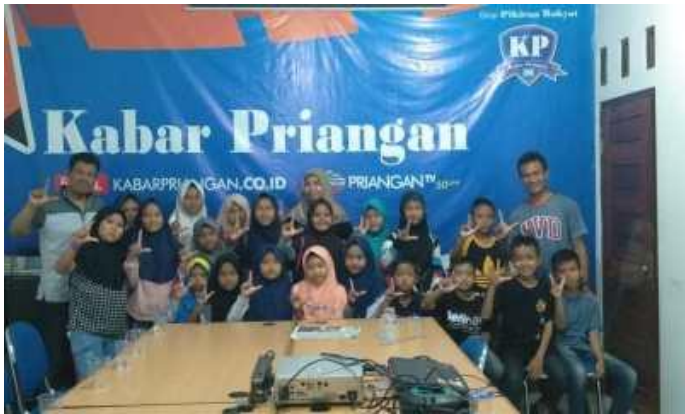

Gambar 2 : Kunjungan Forum Gumelis ke Kabar Priangan

2) Kajian Ilmiah untuk mewujudkan Iklim Akademis

Forum Gumeulis merupakan forum yang fokus terhadap gerakan pemberdayaan guru dalam bidang literasi. Dalam memberdayakan guru forum Gumeulis menggunakan pendekatan bersifat humanistik. Pemberdayaan humanistik merupakan pengakuan atas potensi guru untuk diaktualisasikan melalui pembinaan dan penyediaan iklim akademik yang kondusif, kemudian melakukan pekerjaan secara kreatif. Berdasarkan teori psikologi humanistik disebutkan bahwa tujuan umum ajaran humanis, yaitu: (1) perbaikan komunikasi antara individu, (2) meniadakan individu yang saling bersaing, (3) keterlibatan intelek dan emosi dalam suatu proses belajar, (4) memahami dinamika bekerjasama, dan (5) kepekaan kepada pengaruh perilaku individu lain dalam lingkungan. (Sastrawijaya 1988:80)

Berdasarkan kosep tersebut forum Gumeulis mengadakan kegiatan pemberdayaan melalui pelatihan dan diskusi menuju iklim akademik yang kondusif. Pelatihan dilakukan secara berkala misalnya tiga bulan sekali dengan mendatang tempat-tempat yang telah dijadwalkan. Misalnya per-kecamatan atau pergugus, sesuai dengan kebutuhan dan permintaan anggota di lapangan. Output dari kegiatan ini menghasilkan guru yang berani memulai untuk menulis artikel ilmiah populer. Dan selanjutnya artikel yang layak akan diterbitkan di rubrik Gumeulis kabar priangan. Sementara bagi tulisan yang belum layak disarankan untuk mengikuti pelatihan di tempat lain atau mengikuti kelas literasi. 


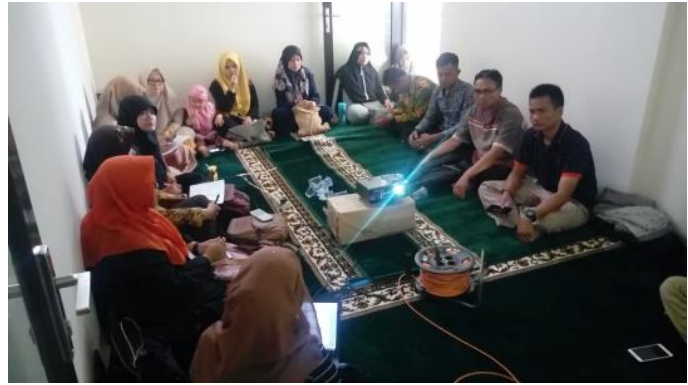

Gambar 3 : Diskusi Kepenulisan

\section{3) Menerbitkan Karya Bersama}

Dalam rangka memberikan motivasi guru untuk dapat menerbitkan hasil karyanya. Forum guru menulis mencoba memfasilitasinya agar dapat terbit. Proses penerbitan tersebut dilakukan melalui kerjasama dengan penerbit professional. Hal ini dimaksudkan agar karya yang akan diterbitkan teruji kualitasnya. Selain itu, melalui kerjasama dengan penerbit profesional akan dapat meningkatkan rasa percaya diri guru terhadap hasil karyanya.

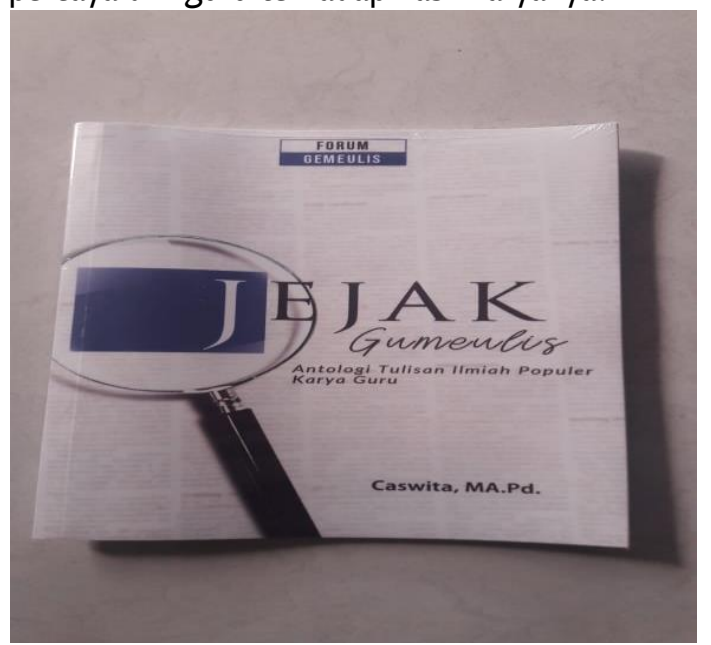

Gambar 4 : Buku Karya Bersama Forum Gumeulis

Hal tersebut merupakan bentuk motivasi bagi para guru yang kebanyakan merupakan penulis pemula. Melalui forum Gumeulis guru akan dapat belajar bersama dan sama-sama untuk belajar. Melalui forum ini akan didiskusikan apa-apa yang perlu dikaji dan penting bagi kepentingan karir guru. Melalui penerbitan karya bersama merupakan jalan bagi guru untuk menjadi penulis dan masuk ke dalam dunia literasi.

Diantara manfaat penerbitan bersama adalah, pertama memperoleh ilmu kepenulisan misalnya tentang teknis penulisan, penggunaan tanda baca, bedah karya, dan kriteria buku.
Dengan menerbitkan karya bersama akan ada peluang antar penulis untuk berbagai ilmu kepenulisan. Selain itu satu sama lain akan mengoreksi karya. Kedua, melatih Kesabaran dan saling memotivasi. Terkadang ketika akan menulis semangat untuk menyelesaikan karya menurun. Dengan menulis bersama akan dapat meningkatkan kembali semangat para penulis yang menurun. Melalui kegiatan saling memotivasi, menjadi cara yang efektif meningkatkan semangat menulis.

Ketiga, sebagai ajang promosi antar penulis. Melalui karya bersama merupakan salah satu cara untuk menambah teman baru yang satu frekuensi di dunia menulis. Tidak jarang setelah sukses menyusun karya, berlanjut dengan acara pelatihan atau diskusi bersama antar para penulis. Kemudian bisa juga saling mempromosikan hasil karya masing-masing. Keempat, Karya bersama sebagai portofolio bagi penulis. Menjadi kebanggan ketika karya ilmiah dapat terbit dan dibaca banyak orang. Karya ilmiah yang telah terbit merupakan salah satu portofolio. Bagi penulis pemula akan terasa sangat bahagia, apabila karyanya dapat diterbitkan dalam bentuk buku, walaupun kumpulan dari karya bersama. Dengan saling memberikan motivasi diantara para penulis, diharapkan akan muncul karya-karya lainnya secara mandiri. (diakses dari bitread.id). Selain itu, forum Gumeulis juga diharapkan mampu muncul motivasi dan semangat para guru dalam membuat karya tulis ilmiah. Melalui forum Gumeulis dapat menciptakan iklim akademik yang kondusif untuk para guru agar mau dan mampu menulis karya tulis ilmiah.

\section{PENUTUP}

\section{Kesimpulan}

Peningkatan kompetensi guru harus dilakukan secara terus menerus, mengingat perkembangan ilmu pengetahuan dan teknologi begitu cepat. Sehingga seorang guru sebagai ujung tombak pendidikan harus mengimbangi perkembangan tersebut. Meningkatkan kompetensi guru bukan hanya kewajiban pemerintah semata, akan tetapi kewajiban semua pihak yang berkepentingan dalam pendidikan. Sementara itu pihak yang paling berpengaruh dalam meningkatakan kompetensi adalah pribadi gurunya sendiri. Selain itu adalah 
lembaga pendidikan tempat guru tersebut bertugas.

Peningkatan kompetensi guru tidak hanya menunggu program pemerintah, akan tetapi yang paling efektif adalah atas dasar kemauan guru sendiri dengan cara membangun komunitas belajar (Learning Community). Pemberdayaan guru yang bersifat kultural atau gerakan dari bawah (buttom up), akan lebih langgeng dibandingkan dengan instruksi dari atas kebawah (top down). Karena kebijakan buttom up berdasarkan kebutuhan, keinginan dan permasalahan yang dihadapi bersama-sama. Oleh karena itu penting bagi guru membentuk komunitas belajar sebagai sarana meningkatkan kompetensi pribadi. Dengan membangun komunitas di harapakan akan tercipta iklim akademik (habits), yang kondusif bagi kegiataan literasi.

Kompetensi yang harus ditingkatkan adalah kemamapuan menulis KTI dan juga motivasi untuk menulis. Selama ini problem kelemahan guru dalam menulis KTI masih harus terus dicarikan solusinya, baik melalui pelatihan, pendamping dan juga belajar bersama melalaui komunitas belajar. Selain itu yang tidak kalah pentingnya adalah memberikan motivasi kepada guru untuk terus menulis dan meningkatkan kemampuannya.

Kehadiran forum Gumeulis merupakan gerakan kultural yang berlandaskan kebutuhan, keinginan dan permasalahan bersama yaitu lemahnya kemampuan guru dalam membuat karya ilmiah. Kehadiran forum Gumeulis diharapkan dapat ikut membantu dalam mengatasi problem lemahnya guru dalam membuat karya tulis ilmiah.

\section{Rekomendasi}

Selanjutnya rekomendasi yang dapat diberikan dari temuan penelitian berupa rekomendasi implikatif adalah sebagai berikut : Bagi Sekolah :
a. Dapat terus mengembangkan profesionalisme guru secara berkesinambungan untuk meningkatkan kualiatas pembelajaran di sekolah.
b. Kepala sekolah sebagai pimpinan tertinggi di sekolah harus terus mencari alternatif

upaya dalam meningkatkan profesionalisme guru khususnya dan pengembangan sekolah pada umumnya.

c. Guru harus menyadari bahwasannya peningkatan profesionalisme tidak bisa dilakukan secara instan akan tetapi harus terencana dan secara berkesinambungan.

d. Sekolah dapat bekerja sama dengan berbagai pihak yang mendukung terhadap kemajuan pendidikan, misalnya dengan media massa, perguruan tinggi, komunitas literasi dan lain sebagainya.

Bagi pemerintah diharapkan menjadi pendukung program sekolah dan komunitas para guru untuk meningkatkan profesionalismenya.

Bagi pengembangan ilmu pengetahuan: penelitian selanjutnya dapat melakukan peneliti tentang peran penting kepala sekolah dalam mewujudkan forum-forum kultural di kalangan guru.

Selanjutnya keberadaan forum Gumeulis diharapkan menjadi komunitas alternatif belajar bagi guru untuk meningkatkan berbagai kompetensi yang diharuskan. 


\section{DAFTAR PUSTAKA}

Afandi, M. (2015). Evaluasi Pembelajaran Sekolah Dasar. Semarang: Unissula Press.

Amir, H. (2019). Sindikat Transaksi Kenaikan Pangkat Terungkap, Dua Guru Gowa...

Aqib, Z. (2007). Penelitian Tindakan Kelas. Bandung: Yrama Widya.

Arikunto, S. (2002). Metodologi Penelitian Suatu Pendekatan Proposal. Jakarta: PT. Rineka Cipta.

Ayusrijuniantari, I. (2017). Pentingnya Peningkatan Kompetensi Guru Dalam Pencapaian Hasil Belajar Siswa. ResearchGate. Retrieved from https://www.researchgate.net/publication/315099985_PENTINGNYA_PENINGKATAN_KOMPETENSI_GURU _DALAM_PENCAPAIAN_HASIL_BELAJAR_SISWA

Daryanto. (2011). Kepala Sekolah Sebagai Pemimpin Pembelajaran. Yogyakarta: Gava Media.

Dermawati. (2017). Peningkatan Pemahaman Guru Terhadap Materi Kurikulum 2013. Andragogi Jurnal Diklat Teknis Pendidikan Dan Keagamaan, 5(1).

Harsanto, R. (2007). Pengelolaan Kelas yang Dinamis. Yogyakarta: Kanisius.

Inayati, N. L. (2014). Peran Kepala Sekolah Dalam Meningkatkan Profesionalisme Guru Di Sekolah Menengah Pertama (SMP) Muhammadiyah 3 Kaliwungu Dan SMP Muhammadiyah 6 Kendal Tahun Ajaran 2013/2014 (Universitas Muhammadiyah Surakarta). Retrieved from http://v2.eprints.ums.ac.id/archive/etd/38341

Mudlofir, A. (2012). Pendidik Profesional: Konsep, Strategi dan Aplikasinya dalam Peningkatan Mutu Pendidikdi Indonesia. Jakarta: Rajawali Press.

Noorjannah, L. (2014). Pengembangan Profesionalisme Guru Melalui Penulisan Karya Tulis Ilmiah Bagi Guru Profesional Di Sma Negeri 1 Kauman Kabupaten Tulungagung. Jurnal Humanity, 10(1), 97 - 114.

Nugroho, H. (2011). Cara Mudah Menjadi Guru Penulis. Semarang: Dahara Prize.

NusaBali.com. (2016). 188 Guru di Karangasem Gagal Naik Pangkat.

Okenews. (2015). Menjiplak, 8.729 Guru Gagal Naik Pangkat.

Rakajoni. (2008). Model Pendidikan Guru dan Pendidikan Dosen, Pra-Jabatan (Makalah disampaikan pada Konvensi Pendidikan Nasional VI dengan tema Pendidikan Bermutu untuk Semua).

Sagala, S. (2007). Manajemen Strategik dalam Peningkatan Mutu Pendidikan. Bandung: Alfabeta.

Sampurno, Y. G., \& Siswanto, I. (2010). Pelatihan Penulisan Karya Tulis Ilmiah bagi Guru-guru Sekolah Dasar di Kecamatan Moyudan Sleman.

Sastrawijaya, T. (1988). Proses Belajar Mengajar Diperguruan Tinggi. Jakarta: Depdikbud: Dirjen Dikti LPTK.

Siagian, S. P. (2002). Manajemen Stratejik. Jakarta: Bumi Aksara.

Sudrajat, A. (2008). Peran Kepala Sekolah dalam Meningkatkan Kompetensi Guru. Retrieved from https://akhmadsudrajat.wordpress.com/2008/01/21/kompetensi-guru-dan-peran-kepala-sekolah/

Sukmadinata, N. S. (2011). Landasan Psikologi Proses Pendidikan. Bandung: PT. Remaja Rosdakarya.

Susanto, A. T., \& Muhyadi. (2016). Peran Kepala Sekolah dalam Pengembangan Kompetensi Guru di Sekolah Menengah Pertama. Jurnal Akuntabilitas Manajemen Pendidikan, 4(No 2). Retrieved from https://journal.uny.ac.id/index.php/jamp/article/view/8029/0

Wahyosumidjo. (2010). Kepemimpinan Kepala Sekolah Tinjauan Teoritik Dan Permasalahannya. Jakarta: PT. Raja Grafindo Persada.

Wardhana, R. A. nandi. (2016). Pengaruh Kepemimpinan Kepala Sekolah, Profesionalisme Dan Pelatihan Guru Terhadap Implementasi Kurikulum 2013 SMKN Yogyakarta. Jurnal Akuntabilitas Manajemen Pendidikan, 4(2). https://doi.org/https://doi.org/10.21831/amp.v4i2.10812

Wibowo, C. H. (2015). Problematika Profesi Guru dan Solusinya bagi Peningkatan Kualitas Pendidikan di MTs Negeri Nguntoronadi Kabupaten Wonogiri. Pascasarjana IAIN Surakarta. 